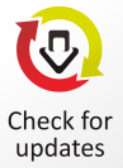

updates

\title{
Credit Value-Relevance of Earnings, Other Comprehensive Income, and Comprehensive Income: A Study on IFRS Adoption Stage in Indonesia
}

\author{
Harjanti Widiastuti* and Elsi Safira
}

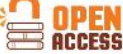 \\ Department of Accounting, Universitas Muhammadiyah Yogyakarta, JL. Brawijaya, Tamantirto, Kasihan, Bantul, Yogyakarta Special Region, Indonesia \\ *Correspondence:@ widiascahyo@gmail.com This article is avalilable in: http://journal.umy.ac.id/index.php/ai DOI: 10.18196/jai.1902101}

\section{Citation:}

Widiastuti, H., \& Safira, E. (2018).

Credit Value-Relevance of Earnings, Other Comprehensive Income, and Comprehensive Income: A Study on IFRS Adoption Stage in Indonesia. Journal of Accounting and Investment, 19(2), 194-209.

Received:

25 February 2018

Reviewed:

30 May 2018

Revised:

21 June 2018

Accepted:

10 July 2018

Copyright: (C) 2018

Widiastuti and Safira. This is an open access article distributed under the terms of the Creative Commons Attribution

License, which permits unrestricted use, distribution, and reproduction in any medium, provided the original author and source are credited.

\begin{abstract}
This research aims to examine the credit value-relevance of net income, other comprehensive income $(\mathrm{OCI})$ and comprehensive income. This research indirectly examines the impact of IFRS adoption on the usefulness of earnings and $\mathrm{OCl}$ information. The credit value-relevance measures the usefulness of accounting information from the creditor perspective, represented by the bond rating agency. In this research, accounting information is said to have credit value-relevance if accounting information affects bond rating. The sample of this research is 495 bond issuer companies listed in Indonesia Stock Exchange period 2011-2016. Hypothesis testing is done by the logit regression test. The results show that net income and comprehensive income have credit-value relevance, whereas $\mathrm{OCI}$ has no credit relevance. The results also find an increase in the credit-value relevance of comprehensive income from the beginning adoption of IFRS (2011) to the first implementation of IFRS adoption.
\end{abstract}

KEYWORDS: credit value-relevance; earnings; other comprehensive income; comprehensive income

\section{Introduction}

The purpose of valuation of financial statements is to provide information useful for the user to make investment and credit valuation decisions. At the empirical level, testing the usefulness of accounting information decisions is done by testing the value relevance. In a broad sense, value relevance is the usefulness testing of accounting figures for various financial reporting purposes. The term "value relevance" has been very popular in literature and accounting research to test the usefulness of accounting figures for stock market investors in order to make investment decision (Barth, Beaver, \& Landsman, 2001; Holthausen \& Watts, 2001). The researchers add the word "credit" to the term "value relevance" to differentiate with value relevance which tests the usefulness of accounting figures for stock market investors. Thus, credit-value relevance tests the usefulness of accounting figures for creditor decision-making. More specifically, testing of credit-value relevance is indicated by the relationship of accounting information with bond yield or rating. This study examines credit-value relevance by relating accounting figures with bond rating as previous researchers did (Hann, Heflin \& Subramanayam, 2007; Jorion, Shi \& Zhang, 2009).

Earnings information is one of the important information required by users of financial statements, including creditors and bond rating agency. Earnings are used to assess company performance and as input to predict 
The company's ability to pay its liabilities. Statement of Financial Accounting Standards (Pernyataan Standar Akuntansi Keuangan, PSAK) 1 (revised 2009) effective in 2011 requires the company to provide the Statement of Comprehensive Income. Comprehensive income (loss) is a sum of net income (loss) and other comprehensive income (OCI).

Other comprehensive income includes the components changes in the fair value of the unrealized asset or debt expected to provide better information about the future prospects. IFRS adoption through PSAK 1 adoption and the obligation to present the statement of comprehensive income is a context or phenomenon that triggers the need for testing the usefulness of $\mathrm{OCl}$ and comprehensive income information from the creditor perspective represented by the bond rating agency. This research is expected to confirm the claims of the standard-setting body that the application of fair value accounting reflected in $\mathrm{OCl}$ and comprehensive income increases the value relevance of accounting information.

This research aims to examine the relationship between accounting figures i.e. net income, $\mathrm{OCl}$, and comprehensive income and bond rating (creditvalue relevance of net income, $\mathrm{OCl}$, and comprehensive income information). This research extends the test by examining the credit-value relevance of $\mathrm{OCl}$ and comprehensive income information at each stage of the International Financial Reporting Standards (IFRS) adoption, i.e. the beginning adoption (2011), the first implementation (2012-2014), and the second implementation (2015-2016). This research indirectly examines the impact of IFRS adoption on the usefulness of accounting information from the creditor perspective. It is done considering the company's obligation to report the comprehensive income is effective in 2011, so the learning effect enables the increase on the credit-value relevance of $\mathrm{OCl}$ and comprehensive income information from the beginning adoption of IFRS to the first and the second implementation of IFRS adoption. This research also tests the credit-value relevance of earnings versus loss and positive versus negative $\mathrm{OCl}$ as additional tests.

This research is important with consideration from theoretical and empirical gaps. Theoretically, the standard-setting body and accounting researches often focus on the usefulness of information for shareholder investment decision-making. In fact, shareholders and debtholders have different information needs. Holthausen and Watts (2001) state that "what is relevant for one user or user group may not be relevant for another. This creates a problem in drawing inferences based on value-relevance research using equity values only". Accounting research on debt or bond markets is relatively limited compared to accounting research in the stock markets. In fact, bond issuance is significant selections of the funding source formost public companies, making debtholders become the significant part of the company's total stakeholders. Most debtholders are institutional investors who pay great attention to the quality of financial reporting.

This research is also motivated by the research gap. From an empirical viewpoint, studies which relate earnings and bond rating information find inconsistent results. Several researchers (Henny, 2016; Kosi, 2010; Lestari \& Yasa, 2014; Magreta \& Nurmayanti, 2009; Mahfudhoh \& Cahyonowati, 2014; Rusfika \& Wahidahwati, 2015) examine the relationship of accounting 
figures, especially between earnings and bond rating. Some studies have found that earnings have a positive effect on bond rating (Henny, 2016; Kosi, 2010; Magreta \& Nurmayanti, 2009; Rusfika \& Wahidahwati, 2015), while some other studies have found that earnings have no effect on bond rating (Lestari \& Yasa, 2014; Mahfudhoh \& Cahyonowati, 2014). The difference is due to the different sample, period of observation, and the bond rating measurement. In addition, based on the literature review, no studies have specifically examined the usefulness of $\mathrm{OCl}$ and comprehensive income information as the result of IFRS adoption from the creditor perspective.

This research contributes in several ways. First, this research adds empirical evidence of the usefulness of accounting information from the relatively limited creditor perspective. Secondly, most previous researches have only tested profitability as measured by net income, while this research examines the credit value-relevance of net income and comprehensive income. Different earnings figures have different semantic meanings, causing different pragmatic effects for the user. Third, extending previous research, this research tests the usefulness of $\mathrm{OCl}$ and comprehensive income information and the usefulness of net income, $\mathrm{OCl}$, and comprehensive income information at each stage of IFRS adoption.

\section{Literature Review and Hypothesis Development}

\section{Signaling Theory}

Signaling theory was originally developed by Spence (1973) to explain the problem of information asymmetry in the labor market. Although initially signaling theory is used to explain the information asymmetry in the labor market, this theory is then used to explain the condition of information asymmetry in other phenomena. Morris (1987) identifies the use of signaling theory to explain the dividend policy issue, capital structure decisions, voluntary disclosure, and retention of shareholdings by management on the new shares issuance, fair value accounting, and auditor selection.

Connelly, Certo, Ireland, and Reutzel (2011) emphasize two key characteristics for the signal to be beneficial to the recipient, i.e. (1) the signal must be observable by the recipient so it can be used to make decisions, and (2) the signal must be costly enough to be imitated by low quality companies. Management has private information, both positive and negative information, and must decide the necessity to communicate the information. The signaling theory focuses on communicating positive information as an effort to convey organizational qualities thus predicting that management will generally not communicate negative signals to reduce information asymmetry.

From the sender of the signal, the signaling theory predicts that a good quality company will choose accounting policies that allow superior quality to be revealed, whereas a poor quality company will choose accounting policies that hide their disrepute. Management signals the unobserved quality of the company to investors through the quality of financial 
statements (Zhang \& Wiersema, 2009). The incentive to signal through the selection of accounting policies will increase when information asymmetry is high. From the recipient of the signal, the signal has quality when it is useful for decision-making.

\section{Other Comprehensive Income (OCI) and Comprehensive Income}

IFRS adoption through PSAK 1 (revised 2009) mandating the preparation of statements of comprehensive income is effective in 2011. PSAK 1 (revised 2009) also requires the provision of other comprehensive income $(\mathrm{OCl})$. Other comprehensive income includes income and expense items (including reclassification adjustments) not recognized in profit or loss as required by other SAKs. Net income and $\mathrm{OCl}$ are components of the comprehensive income. Components of other comprehensive income (OCI) include (1) changes in revaluation surplus (PSAK 16, Property, plant, and equipment and PSAK 19, Intangible assets); (2) actuarial gains and losses on defined benefit plans recognized in accordance with paragraph 94 of PSAK 24, Employee benefits; (3) gains and losses arising from translation of financial statements from foreign entities (PSAK 10, The effects of changes in foreign exchange rates); (4) gains and losses from the measurement of available-for-sale financial assets (PSAK 55, Financial instruments: Recognition and Measurement); and (5) the effective portion of gains and losses on the hedging instrument in the "cash flow hedge" (PSAK 55, Financial instruments: Recognition and Measurement).

Comprehensive income is bottom line income consisting of net income and $\mathrm{OCl} . \mathrm{OCl}$ and comprehensive income are considered less conservative as they allow unrealized profit recognition. In addition, $\mathrm{OCl}$ and comprehensive income are also seen as more volatile than net income because they depend on market conditions. Negative $\mathrm{OCl}$ reflects a decrease in the fair value of an asset greater than its increase, and vice versa. Companies that report a net loss (which more closely reflects the main operating results) in their financial statements may report comprehensive income due to the positive $\mathrm{OCl}$ covers the net loss. Therefore, the usefulness of $\mathrm{OCl}$ and comprehensive income information becomes interesting to be studied mainly from the creditor perspective.

\section{Credit-Value Relevance of Net Income, Other Comprehensive Income, and Comprehensive Income Information}

Creditor is concerned with the financial statement information to assess the ability of the company to fulfill its obligations in the form of loan principal or interest or default risk. Default risk reflects the risk of loss arising from the debtor's inability to pay its obligations. Credit rating reflects the scale of credit risk or security level. The better the credit rating is, the lower the credit risk will be. With these definitions, the need for accounting information from the creditor perspective is represented by the bond rating agency through bond rating information.

One of the financial statement information used as an input in estimating the company's ability to pay the loan is earnings information. If the company's earnings are high, then the company is expected to be able to 
meet its obligations. Consequently, the default risk will decrease and the bond rating from the issuing company will increase. The adoption of PSAK 1 (revised 2009) requiring the company to present the statement of comprehensive income implies some information on the earnings figure, i.e. comprehensive income as bottom line income, net income, and other comprehensive income. Each of these figures is expected to have creditvalue relevant, albeit at different levels, depending on the inherent characteristics of the earnings figures.

Net income is seen as more conservative than comprehensive income because comprehensive income allows the entry of unrealized income. In fact, lenders prefer conservative earnings because it reduces the risk of dividend distribution (Watts, 2003). However, OCl and comprehensive income are also expected to provide additional information in net income. From the viewpoint of contract efficiency with the lenders, the application of fair value accounting can represent the fair value of the asset to increase the efficiency of debt covenant negotiations. The fair value method is preferred by the company with high leverage because the fair value of the asset provides better information in reflecting the company's ability to repay the loan (Christensen \& Nikolaev, 2013).

According to agency theory, comprehensive income provides information that reflects the real conditions and approximates economic earnings thus decreasing information asymmetry. When comprehensive income is used as the basis in debt agreements, the decrease in information asymmetry between management and creditors will also decrease the agency cost of debt. Comprehensive income information will also provide more complete information about the company's future prospects and assess the company's ability to repay the debt thereby decreasing the information asymmetry between creditors (bondholders).

The signaling theory predicts that assets and liabilities presented at fair value indicate the better value of liquidity than cost. Accordingly, changes in the fair value of assets and liabilities presented in the statement of comprehensive income are expected to provide better information on the value of liquidity. If the creditor has an interest in predicting the possibility of default, then the comprehensive income should have higher credit-value relevance than the net income as it reflects the real fluctuations of the company's performance.

Previous research results show that net income has credit-value relevance. Ziebart \& Reiter (1992) examine the relationship between accounting information, bond rating, and bond yield with bond samples issued in the 1981-1985 period and rated by Standard and Poor's (S \& P) and Moody's. The results show that financial information affects bond rating and directly or indirectly affects bond yield through bond rating. Kosi (2010) which uses companies with bond rating from $S \& P$ and Worldscope rating agencies in the period 1999 - 2009 as the sample shows that net income has creditvalue relevance. Rusfika and Wahidahwati (2015) with non-financial bond issuer companies in the period 2010-2013 as the sample conclude that net income has credit-value relevance. With a different study period, Henny (2016) and Magreta and Nurmayanti (2009) find that net income affects 
bond rating. Based on the above theoretical explanation, the hypotheses are drawn as follows:

$H_{1 a}$ : Net income has credit-value relevance

$H_{1 b}$ : Comprehensive income has credit-value relevance

$H_{1 c}$ : Other comprehensive income $(\mathrm{OCl})$ has credit-value relevance.

\section{Credit-value relevance of Net income, Other Comprehensive Income, and Comprehensive Income Information at the Adoption Stage of IFRS}

IFRS adoption with the principal basis and more emphasis on the use of fair value in the measurement of company assets and debt imply the presentation of financial statements in accordance with the underlying substance of the transaction and the economic event. Thus, IFRS adoption is expected to improve the quality of financial statement information. Improved quality of financial statements is very useful and used by users in economic decision-making, making the higher value relevance of financial statement information. For this reason, IFRS adoption is also expected to increase credit value-relevance.

On the other hand, IFRS adoption also implies the need for higher professional judgment in the preparation of financial statements, causing the better quality of human resources is needed, in terms of financial statements compilers and auditors. It means that the considered-better new standards adoption does not necessarily result in better financial statements as the quality of financial statements compilers and auditors has an important role. In fact, understanding and mastery of new standards and competencies require effort and time so that the quality improvement of the financial statements due to standard changes will be achieved gradually. It is the alleged reason behind the difference in credit-value relevance at every stage of IFRS adoption.

PSAK 1 (revised 2009) mandating the preparation of the statements of comprehensive income is effective in 2011. The compilation of the statements of comprehensive income is considered more complex as it includes measurement components of the changes in the fair value of assets and liabilities depending on market conditions and requires a higher professional judgment in its application. The IFRS adoption stage reflects the learning process on the implementation of new standards for financial statements compilers and auditors. The longer standard implementation is expected to increase the understanding and skill of the financial statements compilers and auditors in implementing these standards. The improvement of the skills and understanding of financial statements compilers and auditors in implementing new standards will improve the quality of financial reporting. Quality and reliable financial reports will improve the usefulness of decision making, including in bond rating.

Kosi (2010) examines the credit-value relevance of net income before and after the IFRS adoption by using bond rating as the dependent variable. Using the countries that entered the European Union in 2002-2007 (In 2005, IFRS was mandatory to be adopted in the European Union) as the sample, the results indicate that credit-value relevance after IFRS adoption is higher 
than credit-value relevance before IFRS adoption. Based on the above theoretical explanation, the hypothesis is drawn as follows:

$\mathrm{H}_{2}$ : There is an increase in credit-value relevance of $\mathrm{OCl}$ and comprehensive income at the IFRS stage.

\section{Research Method}

\section{Population and Sample}

The object of this research is all bond issuer companies listed in Indonesia Stock Exchange (IDX) in period 2011-2015. Sampling is done by purposive sampling method, with criterion (1) company listed in Indonesia Stock Exchange issuing outstanding rupiah-denominated bonds in the period 2011-2016, (2) the company is included in the company bond rating by PT PEFINDO, and (3) the company publishes the financial report which can be downloaded on the IDX website in the research period. The research data is secondary data in the form of financial report (2011) -2015) and bond rating (2012-2016).

\section{Operational Definitions and Measurements of Variables}

The dependent variable in this research is bond rating, while the independent variables include net income, $\mathrm{OCl}$, and comprehensive income. Bond rating is a grade from bond issuer companies that indicates the default risk of a company. The better the bond rating is, the lower the default risk will be. Bond rating in this research is the company rating issued by PT Pefindo. Bond rating is given in the range of AAA (highest rank) and D (lowest rank). PT Pefindo classifies bond rating into two categories, i.e. investment grade ( $A A A, A A, A, B B B)$ and speculative grade $(B B, B, C C C, D)$. If the classification follows PT Pefindo's rating, the research sample is not representative for testing because very few companies have downward BB bond rating. Based on these considerations, this research classifies bond rating into first grade and second grade.

The company has the first-grade classification if it has bond rating of AAA, $A A$, and $A$ (good + , none -) and has the second grade classification if it has bond rating of $\mathrm{BBB}, \mathrm{BB}, \mathrm{B}, \mathrm{CCC}$, and $\mathrm{D}$. Measurement of bond rating uses dummy variables i.e. the value of 1 for the first-grade category, and the value of 0 for the second-grade category. Net income is measured by the amount of net income of the current year after tax. Comprehensive income is measured by the amount of comprehensive income, and $\mathrm{OCl}$ is measured by the total amount of $\mathrm{OCl}$. Net income, comprehensive income, and $\mathrm{OCl}$ are deflated by total assets. Company size is measured by the natural logarithm of total assets.

\section{Data Analysis and Hypothesis Testing}

Data analysis includes descriptive analysis to examine the characteristics of sample data and inferential analysis to test the research hypothesis. 
Hypothesis testing is done by logistic regression analysis. The regression equation for hypothesis testing is as follows:

$\ln \left(\frac{p}{1-p}\right)=\beta_{0}+\beta_{1} X_{1}+\beta_{2} X_{2}$

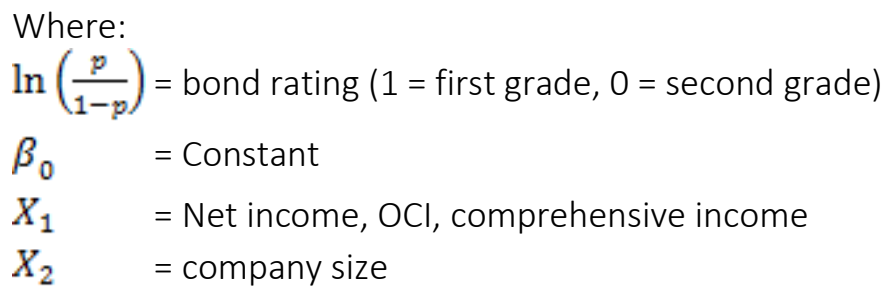

The testing of net income influence is conducted on the full sample (to increase the sample quantity and predictability), while the testing of $\mathrm{OCl}$ and comprehensive income are done on the companies with $\mathrm{OCl}$ (comprehensive income is different from net income). Testing the usefulness of net income, $\mathrm{OCl}$, and comprehensive income information at each IFRS stage is done with the above regression model for 2011 samples (the beginning), 2012-2014 samples (the first implementation), and 2015-2016 samples (the second implementation). Data analysis is conducted by looking at model feasibility (Hosmer and Lemeshow test), pseudo-coefficients of determination (Nagelkerke R Square), and the hypothesis test (Wald test). Hypothesis one $\left(\mathrm{H}_{1 a}, \mathrm{H}_{1 b}, \mathrm{H}_{1 c}\right)$ is supported if it has positive estimation coefficient and pa -value less than 0.05 . Hypothesis $2\left(\mathrm{H}_{2}\right)$ is supported if it has positive estimation coefficient, pa -value less than 0.05 , and Nagelkerke $\mathrm{R}$ Square increases in each IFRS adoption stage.

\section{Result and Discussion}

\section{Descriptive Statistics}

Bond issuer companies listed on the IDX and have outstanding bonds in the period 2011-2016 which become the sample of this research are 495 company-year. Of 495 company-year, 134 company-year do not have OCl. Companies with no $\mathrm{OCl}$ mean net income equals comprehensive income. Therefore, testing the credit-value relevance of $\mathrm{OCl}$ and comprehensive income uses the sample of companies with $\mathrm{OCl}$ (361 company-year). Descriptive statistical results are presented in Table 1.

The sample company has average total assets of IDR 52,070,474.773 million. The sample company has an average net income of $4.06 \%$ and comprehensive income of $4.3 \%$ of total assets. In general, first-grade companies perform better than second-grade companies, as indicated by higher net income and comprehensive income. Average net income on companies with first-grade rating (rated AAA to A-) is 0.047171, while average net income in companies with second-grade rating (rated BBB to D) is -0.005739 . Descriptive statistics indicate that companies with first-grade rating have a positive earnings average, while companies with second-grade rating have negative earnings average. These results indicate that the information on net income is related to the bond rating. 
Table 1 Descriptive Statistic

\begin{tabular}{|l|l|c|c|c|c|c|}
\multicolumn{1}{c}{ Variabel } & Category & $n$ & Mean & Stand. Dev. & Minimum & Maximum \\
\hline \multirow{2}{*}{ Net Income } & Full sampel & 495 & 0,040651 & 0,088313 & $-0,4843$ & 1,5209 \\
\cline { 2 - 7 } & First grade & 434 & 0,047171 & 0,09040 & $-0,4843$ & 1,5209 \\
\cline { 2 - 7 } & Second grade & 61 & $-0,005739$ & 0,09040 & $-0,4843$ & 0,1857 \\
\hline \multirow{2}{*}{ OCI } & Full sampel & 361 & 0,006979 & 0,04496 & $-0,0296$ & 0,5757 \\
\cline { 2 - 7 } & First grade & 320 & 0,005312 & 0,03490 & $-0,0296$ & 0,5237 \\
\cline { 2 - 7 } & Second grade & 41 & 0,019992 & 0,09101 & $-0,0165$ & 0,5757 \\
\hline \multirow{2}{*}{$\begin{array}{l}\text { Comprehenen } \\
\text { income }\end{array}$} & Full sampel & 361 & 0,043334 & 0,10223 & $-0,4919$ & 1,5228 \\
\cline { 2 - 7 } & First grade & 320 & 0,046938 & 0,09656 & $-0,0907$ & 1,5228 \\
\hline \multirow{2}{*}{ Size } & Second grade & 41 & 0,015202 & 0,13723 & $-0,4919$ & 0,5859 \\
\hline
\end{tabular}

Average $\mathrm{OCl}$ is $0.6 \%$ of total assets. The average positive $\mathrm{OCl}$ indicates that the sample companies report an increase in the fair value of the assets or a decrease in the fair value of the liabilities, such as an increase in the revaluation surplus. The interesting results are shown from the average OCl values in the sample with first grade and second-grade rating bond. Companies with second-grade bond rating have higher average OCI (1.9\% of total assets) than companies with first-grade bond rating (0.5\%). These results indicate that companies with second-grade bond rating utilize positive $\mathrm{OCl}$ reporting as a means to make better earnings figures (bottom line income i.e. comprehensive income). This is indicated by second-grade companies having a negative average net income become having a positive average comprehensive income.

\section{Hypothesis Testing Results}

The testing result of hypothesis one is presented in Table 2. H1a testing is done at the bond issuer company in the period 2011-2016, while H1b and $\mathrm{H} 1 \mathrm{c}$ testing are done on bond issuer company in the period 2011-2016 having $\mathrm{OCl}$. The result of hypothesis testing using logistic regression shows that Hosmer and Lemeshow test's value shows significance value above 0,05 , which means that regression model can predict the observation value and there is a match between the regression model and empirical data.

The value of pseudo-coefficients of determination (Nagelkerke $R$ Square) shows net income explain 34,9\% variation of bond rating, while $\mathrm{OCl}$ and comprehensive income respectively explain $17.2 \%$ and $18,7 \%$ variation of bond rating. These results indicate that net income has higher explanatory power (34.9\%) than comprehensive income (17.2\%). This indicates that net income has higher credit-value relevance than comprehensive income. Comparison of models $1 \mathrm{a}$ and model $1 \mathrm{~b}$ (as sensitivity testing) shows an increase in Nagelkerke R Square from $26.5 \%$ to $28.1 \%$ when model $1 \mathrm{~b}$ adds the $\mathrm{OCl}$ variable. This indicates that $\mathrm{OCl}$ provides incremental information on net income.

The testing result of hypothesis 1 shows that net income has positive regression coefficient and significance value less than $5 \%$, both tested with full sample $(n=495)$, with sample company having OCI $(n-361)$, as well as with model of incremental value relevance testing. The comprehensive income also has a positive regression coefficient of 6.369 and is significant. 
Table 2 Hypothesis Testing Results 1

Relevance-value Information Credit Net Income, $\mathrm{OCl}$, and Comprehensive Income

\begin{tabular}{|c|c|c|c|c|c|c|c|}
\hline Model & Variable & $n$ & $\begin{array}{l}\text { Nagelkerke } \\
\text { R Square }\end{array}$ & $\begin{array}{l}\text { Hosmer and } \\
\text { Lemeshow test }\end{array}$ & B & Wald & Sig. \\
\hline \multirow{3}{*}{ Model 1} & Constants & \multirow{3}{*}{495} & \multirow{3}{*}{0,349} & \multirow{3}{*}{0,133} & $-16,997$ & 32,774 & 0,000 \\
\hline & Net Income & & & & 26,417 & 29,5 & 0,000 \\
\hline & Size & & & & 0,800 & 37,443 & 0,000 \\
\hline \multirow{3}{*}{ Model 1a } & Constants & \multirow{3}{*}{361} & \multirow{3}{*}{0,265} & \multirow{3}{*}{0,136} & 20,748 & 12,610 & 0,000 \\
\hline & Laba bersih & & & & 0,695 & 22,559 & 0,000 \\
\hline & Size & & & & $-14,588$ & 18,801 & 0,000 \\
\hline \multirow{4}{*}{$\begin{array}{l}\text { Model } 1 \mathrm{~b} \\
\text { (incremental) }\end{array}$} & Constants & \multirow{4}{*}{361} & \multirow{4}{*}{0,281} & \multirow{4}{*}{0,150} & 20,404 & 12,332 & 0,000 \\
\hline & Net Income & & & & $-6,239$ & 3,162 & 0,000 \\
\hline & $\mathrm{OCl}$ & & & & 0,707 & 23,494 & 0,075 \\
\hline & Size & & & & $-14,776$ & 19,533 & 0,000 \\
\hline \multirow{3}{*}{ Model 2} & Constants & \multirow{3}{*}{361} & \multirow{3}{*}{0,172} & \multirow{3}{*}{0,605} & $-13,859$ & 18,209 & 0,000 \\
\hline & $\mathrm{OCl}$ & & & & $-6,352$ & 3,607 & 0,058 \\
\hline & Size & & & & 0,689 & 23,399 & 0,000 \\
\hline \multirow{3}{*}{ Model 3} & Constants & \multirow{3}{*}{361} & \multirow{3}{*}{0,187} & \multirow{3}{*}{0,529} & $-14,157$ & 17,892 & 0,000 \\
\hline & Comprehensive Income & & & & 6,369 & 3,952 & 0,047 \\
\hline & Size & & & & 0,690 & 22,182 & 0,000 \\
\hline
\end{tabular}

This means that net income and comprehensive income have a positive effect on bond rating. Hence, hypothesis $1 a$ and hypothesis $1 c$ stating that net income and comprehensive income have credit-value relevance are successfully supported.

$\mathrm{OCl}$ has a negative regression coefficient with a significance value of 0.075 (model 1b) and 0.057 (model 2), meaning $\mathrm{OCl}$ either individually or incrementally has no effect on bond rating. Thus, hypothesis $1 \mathrm{~b}$ stating that $\mathrm{OCl}$ has credit-credit relevance is unsuccessful. Control variable of company size has positive and significant regression coefficients across all models. The larger the company is, the more likely it gets a good bond rating. It means that the company size is considered by the bond rating agency in determining bond rating. A large company is usually able to diversify its specific risks so that bond risk will be lower.

The testing result of the effect of earnings on bond rating shows that net income and comprehensive income have a significant and positive effect on bond rating. Thus, net income and comprehensive income have credit-value relevance. This result is consistent with the prediction of the signaling theory that net income and comprehensive income signify the company's performance and future cash flow prospects that can help bond investors and bond rating agency predict the company's ability to pay debts and the probability of default. The better performance indicates the low default risk, so the more likely it is to get the first-grade bond rating. This research supports the measurement perspective in accounting. The measurement perspective of the decision usefulness is the approach in financial reporting in which accountants take the responsibility to include fair value in the main financial statements with adequate reliability in the provision. Thus, accountants feel more obliged to help investors in predicting the company value. This finding is consistent with researches from Henny (2016), Kosi 
(2010), Magreta and Nurmayanti (2009), and also Rusfika and Wahidahwati (2015).

Other findings (based on Nagelkerke R Square) show that net income has higher explanatory power (34.9\%) than comprehensive income (17.2\%). Although net income and comprehensive income are found to have creditvalue relevance, these findings indicate net income has higher credit-value relevance than comprehensive income. In general, the measurement of assets and liabilities with fair value reflected in comprehensive income is seen as providing information that reflects economic substance more and reports accounting earnings close to economic earnings (Penman, 2007). Comprehensive income has credit-value relevance because it reflects the real condition of the company so it is useful to assess the probability of default. However, fair value reporting is criticized for subjectivity and judgment in estimating fair value, especially for non-tradable assets and liabilities. Thus, it can reduce the reliability of the fair value estimates. Fair value implementation may be used by management to convey private information about future disbursements (signaling), but may otherwise be used to manipulate the value of assets and liabilities (opportunists).

The testing results of the effect of $\mathrm{OCl}$ on bond rating show interesting findings. The results show that $\mathrm{OCl}$ has no effect on bond rating. $\mathrm{OCl}$ having no credit-value relevance indicates that the bond rating agency is less considering $\mathrm{OCl}$ in bond rating. $\mathrm{OCl}$ is considered to lack of value-added information on performance information contained in net income. Although $\mathrm{OCl}$ is expected to provide additional information on the real condition of the company, creditors may consider $\mathrm{OCl}$ as transitory and its realization is heavily dependent on changes in economic conditions, making it is less considered in credit evaluation.

Jones and Smith (2011) find that gain and loss of OCl has a negative persistence (possibly reversing in the next period) so that the ability to predict future earnings and cash flows is lower. Descriptive statistics show that average positive $\mathrm{OCl}$ indicates that $\mathrm{OCl}$ is dominated by unrealized profit while conservative creditors need more information about unrealized losses. Another explanation is the possibility that creditors doubt the reliability of $\mathrm{OCl}$ information because $\mathrm{OCl}$ can be used by management as earnings management. Chiorean, Kirschenheiter, and Ramakrishnan (2017) find that management uses unrealized gain and loss of current hedges as a means for earnings management.

The value relevance of net income, $\mathrm{OCl}$, and comprehensive income in IFRS adoption stage are presented in Table 3. IFRS adoption stage is divided into 3 stages, i.e. the beginning adoption (2011), the first implementation (20122014), and the second implementation (2015-2016). The relevance testing of net income is performed on the full sample (including companies with no $\mathrm{OCl}$ ), whereas value relevance testing of $\mathrm{OCl}$ and comprehensive income is conducted on companies with $\mathrm{OCl}$.

Based on Table 3, the testing results of the credit-value relevance of net income information at each stage of IFRS in the full sample indicate that net income has positive and significant regression coefficients in the beginning adoption, the first implementation, and the second implementation. As the 
Table 3 Hypothesis Testing Results 2

Relevance-value Information Credit Net Income, $\mathrm{OCI}$, and Comprehensive Income at IFRS Stage

\begin{tabular}{|c|c|c|c|c|c|c|c|}
\hline Variable & Model & $n$ & $\begin{array}{l}\text { Nagelkerke } \\
\text { R Square }\end{array}$ & $\begin{array}{c}\text { Hosmer and } \\
\text { Lemeshow test }\end{array}$ & B & Wald & Sig. \\
\hline \multirow{3}{*}{$\begin{array}{l}\text { Net Income } \\
(n=495)\end{array}$} & $\begin{array}{l}\text { Pre IFRS Adoption } \\
\text { (2011) }\end{array}$ & 67 & 0,494 & 0,982 & 17,497 & 5,266 & 0,022 \\
\hline & $\begin{array}{l}\text { IFRS Adoption Stage } 1 \\
(2012-2014)\end{array}$ & 275 & 0,451 & 0,886 & 42,161 & 19,204 & 0,000 \\
\hline & $\begin{array}{l}\text { IFRS Adoption Stage } 2 \\
(2015-2016)\end{array}$ & 153 & 0,203 & 0,009 & 18,314 & 6,639 & 0,010 \\
\hline \multirow{3}{*}{$\mathrm{OCl}(\mathrm{n}=361)$} & $\begin{array}{l}\text { Pre IFRS Adoption } \\
\text { (2011) }\end{array}$ & 38 & 0,326 & 0,641 & 316,709 & 1,650 & 0,199 \\
\hline & $\begin{array}{l}\text { IFRS Adoption Stage } 1 \\
(2012-2014)\end{array}$ & 170 & 0,184 & 0,731 & 14,322 & 0,131 & 0,718 \\
\hline & $\begin{array}{l}\text { IFRS Adoption Stage } 2 \\
(2015-2016)\end{array}$ & 153 & 0,156 & 0,555 & $-5,716$ & 3,226 & 0,072 \\
\hline \multirow{3}{*}{$\begin{array}{l}\text { Comprehensive } \\
\text { Income }(n=361)\end{array}$} & $\begin{array}{l}\text { Pre IFRS Adoption } \\
\text { (2011) }\end{array}$ & 38 & 0,358 & 0,937 & 9,274 & 1,154 & 0,283 \\
\hline & $\begin{array}{l}\text { IFRS Adoption Stage } 1 \\
(2012-2014)\end{array}$ & 170 & 0,341 & 0,528 & 39,252 & 6,178 & 0,013 \\
\hline & $\begin{array}{l}\text { IFRS Adoption Stage } 2 \\
(2015-2016)\end{array}$ & 153 & 0,120 & 0,077 & $-0,638$ & 0,038 & 0,846 \\
\hline
\end{tabular}

result of the first hypothesis testing, net income has a positive effect on bond rating. The pseudo-coefficients of determination (Nagelkerke $\mathrm{R}$ Square) shows there is a decrease in explanatory power from $49.4 \%$ in the beginning adoption to $20.3 \%$ in the second implementation. $\mathrm{OCl}$ is found to have no effect on bond rating at all stages of IFRS adoption. These results are also consistent with the findings in the full sample. The testing results of the credit-value relevance of comprehensive income show a positive regression coefficient of 39.252 and significant only in 2012-2014 (the first implementation), whereas in the beginning adoption and the second implementation are found to have no effect. Based on these findings, it can be concluded that the second hypothesis stating that there is an increase in credit-value relevance of $\mathrm{OCl}$ and comprehensive income at the IFRS stage is not successfully supported.

The testing results show that net income has the credit-value relevance of earnings at various IFRS stages and actually there is a decrease in creditvalue relevance when viewed from the explanatory power. For net income, there is relatively no change due to the adoption of PSAK 1 (revised 2009) or the adoption of IFRS-based PSAK in general. Implementation of fair value measurement of assets and liabilities as the key feature of IFRS adoption primarily impacts on comprehensive income rather than on net income. The decrease in the value relevance of net income is likely due to the availability of information other than earnings information on which bond rating is based.

$\mathrm{OCl}$ is found to have no effect on bond rating at each IFRS stage, consistent with the findings in all samples. It is likely due to the small proportion of $\mathrm{OCl}$ to company total assets which is indicated by average $\mathrm{OCl}$ is $0.6 \%$ of total assets, causing it to be less considered in bond rating. So, although theoretically $\mathrm{OCl}$ information is expected to give a signal about the future 
prospects of the company, the low value makes it be less considered in decision-making, including in bond rating. In addition, investors also consider "below the line" $(\mathrm{OCl})$ items as less persistent financial statements items (Barton, Hansen, \& Pownall, 2010).

The testing results of the credit-value relevance of comprehensive income show an interesting phenomenon. In the first year of PSAK 1 (2011), comprehensive income has no effect on bond rating. Comprehensive income has credit-value relevance on the first IFRS implementation (2012-2014) and has no credit-value relevance on the second IFRS implementation (20152016). These findings suggest that there is an increase in the credit-value relevance of comprehensive income information from the beginning adoption (the first year of PSAK 1 revised 2009 is effective) to the first IFRS implementation. This increase can be explained in two ways. First, companies reporting OCl in the first year of PSAK 1 revised 2009 adoption (in 2011) are still relatively few with the smaller value. The average OCI in 2011 was $-0.007 \%$, while the average $\mathrm{OCl}$ in the second implementation (20122014) was $0.15 \%$. The sample companies in 2011 were 67 companies and 38 companies $(57 \%)$ reported $\mathrm{OCl}$.

The sample companies in 2012-2014 were 275 companies and 170 companies (62\%) companies reported $\mathrm{OCl}$. These data indicate an increase in the average value of $\mathrm{OCl}$ as well as the number of companies reporting OCl from 2011 to 2012-2014. Secondly, the first IFRS implementation (20122014 ) is the starting point or a new era of IFRS-based accounting standards welcomed enthusiastically by companies with exceptional learning processes in the implementation. In the application of fair value accounting and the preparation of the statements of comprehensive income, compilers and auditors already have a better understanding than the beginning stage to improve the quality of financial statements. Moreover, these findings are consistent with the signaling theory that comprehensive income is perceived to provide better signals regarding the performance and prospects of companies thus increasing credit-value relevance. These findings are consistent with Kosi (2010) that there is an increase in the credit-value relevance on companies that adopt IFRS mandatively for the first time and only in countries with strong investor protection, although Kosi (2010) uses net income, not comprehensive income. Comprehensive income having no credit-relevance on the second implementation is probably due to the release of new standards which affect the measurement of the fair value of assets and debts that are different from the first implementation period.

\section{Conclusion}

This research aims to examine the credit value-relevance of net income, $\mathrm{OCl}$, and comprehensive income. The credit value-relevance measures the usefulness of accounting information from the creditor perspective, represented by the bond rating agency. In this research, accounting information is said to have credit-value relevance if accounting information affects bond rating. With the sample of 495 bond issuer companies (361 companies with $\mathrm{OCl}$ ) in the period 2011-2016, this research finds that net income and comprehensive income have credit-value relevance. These 
results support the signaling theory that earnings measure the company performance and signal the company ability to fulfill obligations so it is useful to predict the probability of default reflected in the company bond rating. $\mathrm{OCl}$ is found to have no credit-value relevance. Three possible explanations of $\mathrm{OCl}$ having no credit-value relevance are (1) OCl values are still too low in decision-making, (2) OCl is seen as less persistent, and (3) OCl is the object of earnings management.

This research also examines the credit-value relevance of net income, $\mathrm{OCl}$, and comprehensive income at each adoption stage. The results show that net income is consistently found to have credit-value relevance at every stage of IFRS adoption, whereas comprehensive income is found to have credit-value relevance in the first implementation. This testing indirectly examines the impact of IFRS adoption on the usefulness of earnings information. Comprehensive income presentation seems to be useful and attracts the attention of creditors and the bond rating agency on the first implementation of IFRS adoption in 2012-2014. However, at the second implementation of IFRS adoption, comprehensive income has no creditvalue relevance. These results do not support the hypothesis that there is an increase in the credit-value relevance of net income, $\mathrm{OCl}$, and comprehensive income.

These findings do not support the standard-setting body's claim that IFRS adoption will improve the quality of financial statements and ultimately improve the usefulness of accounting information (which is proxied by value relevance). These findings have the theoretical implications that the application of accounting standards, especially the application of fair value accounting, does not necessarily improve the quality of financial statements. The tradeoff between the relevance and reliability of fair value accounting remains an unresolved issue. The findings also have practical implications i.e. the need for the standard-setting body and the regulatory body (Financial Services Authority, Otoritas Jasa Keuangan) to implement IFRS-based accounting standards with benefits exceeding the cost and to improve the quality of financial statements through law enforcement, disclosure regulations, and regulation of corporate governance.

This research has limitations in the few numbers of companies with noninvestment or speculative grade bond rating (BB, $C$, and $D$ ) which impact on the classification of bond rating. This research classifies the first-grade (AAA, $A A, A)$ and second grade $(B B B, B B, B, C, D)$ bond rating which may bring different results when different classifications are used. This research uses the sample of all bond issuer companies listed on the IDX including the finance and banking industries without controlling industrial effects. Subsequent research can use non-financial industry and bank as the sample or be specific to the financial and banking industries. Subsequent research can add auditor quality variables, $\mathrm{OCl}$ component disclosure levels, and corporate governance as the mediating variable of the effect of earnings and $\mathrm{OCl}$ information on bond rating. Auditor quality variables, $\mathrm{OCl}$ component disclosure level, and corporate governance supposedly improve the reliability and quality of $\mathrm{OCl}$ and comprehensive income information so as to improve credit-value relevance. 


\section{References}

Barth, M. E., Beaver, W. H., \& Landsman, W. R. (2001). The relevance of the value relevance literature for financial accounting standard setting: Another View. Journal of Accounting and Economics, 31, 77-104. doi: 10.1016/S0165-4101(01)00019-2

Barton, J., Hansen, T. B., \& Pownall, G. (2010). Which performance measures do investors around the world value the most-and why? Accounting Review, 85(3), 753-789. doi: 10.2308/accr.2010.85.3.753

Chiorean, R., Kirschenheiter, M., \& Ramakrishnan, R. (2017). Earnings Management Through OCI Components. doi: 10.3386/w19846

Christensen, H. B., \& Nikolaev, V. V. (2013). Does fair value accounting for non-financial assets pass the market test?. Review Accounting Studies, 18, 734-775. doi: 10.1007/s11142-013-9232-0

Connelly, B. L., Certo, S. T., Ireland, R. D., \& Reutzel, C. R. (2011). Signaling theory: A review and assessment. Journal of Management, 37(1), 39-67. doi: $10.1177 / 0149206310388419$

Hann, R. N., Heflin, F., \& Subramanayam, K. R. (2007). Fair-value pension accounting. Journal of Accounting and Economics, 44, 328-358. doi: 10.1016/j.jacceco.2007.04.001

Henny. (2016). Pengaruh faktor akuntansi terhadap prediksi peringkat obligasi. Jurnal Akuntansi, XX(01), 52-69.

Holthausen, R. W., \& Watts, R. L. (2001). The relevance of the value-relevance literature for financial accounting standard setting. Journal of Accounting and Economics, 31, 3-75.

Ikatan Akuntan Indonesia. (2009). Pernyataan standar akuntansi keuangan. Jakarta: Salemba Empat.

Jones, D. A., \& Smith, K. J. (2011). Comparing the value relevance, predictive value, and persistence of other comprehensive income and special items. The Accounting Review, 86(6), 2047-2073. doi: 10.2308/accr-10133

Jorion, P., Shi, Æ. C., \& Zhang, Æ. S. (2009). Tightening credit standards : the role of accounting quality. Review Accounting Studies, 14, 123-160. doi: $10.1007 / \mathrm{s} 11142-007-9054-\mathrm{z}$

Kosi, U. (2010). Credit relevance of accounting information and mandatory IFRS adoption. Paper was Presented at An Enterprise Odyssey International Conference Proceeding, University of Zagreb (pp. 662-683).

Lestari, K. Y., \& Yasa, G. W. (2014). Pengaruh penerapan corporate governance dan profitabilitas terhadap peringkat obligasi. E-Jurnal Akuntansi Universitas Udayana, 8(1), 227-249.

Magreta, \& Nurmayanti, P. (2009). Faktor-faktor yang mempengaruhi prediksi peringkat obligasi ditinjau dari faktor akuntansi dan non akuntansi. Jurnal Bisnis dan Akuntansi, 11(3), 143-154.

Mahfudhoh, R. U., \& Cahyonowati, N. (2014). Analisis faktor-faktor yang mempengaruhi peringkat obligasi. Diponegoro Joumal of Accounting, 1(1), 113. Retrieved from http://ejournal-s1.undip.ac.id/index.php/accounting

Morris, R. D. (1987). Signalling, Agency Theory and Accounting Policy Choice. Accounting and Business Research. doi: 10.1080/00014788.1987.9729347

Penman, S. H. (2007). Financial reporting quality: is fair value a plus or a minus?. Accounting and business research, 37(sup1), 33-44. doi: 10.1080/00014788.2007.9730083

Rusfika, \& Wahidahwati. (2015). Kemampuan faktor akuntansi dan non akuntansi dalam memprediksi bond rating. Jurnal Ilmu \& Riset Akuntansi, $4(4), 1-18$.

Spence, M. (1973). Job market signaling. Quarterly Journal of Economics, 355-374.

Watts, R. (2003). Conservatism in accounting part ii: evidence and research opportunities. Accounting Horizons, 17(4), 287-301. doi:

10.2308/acch.2003.17.4.287 
Zhang, Y., \& Wiersema, M. F. (2009). Stock market reaction to ceo certification: The signaling role of CEO background. Strategic Management Journal, 30, 693-710. doi: 10.1002/smj

Ziebart, D. A., \& Reiter, S. A. (1992). Bond ratings, bond yields and financial information. Contemporary Accounting Research, 9(1), 252-282. doi: 10.1016/S0165-4101(01)00019-2 